\title{
Karakteristik Klinis Lupus Eritematosus Sistemik pada Anak
}

\author{
*Ni Putu Sudewi, Nia Kurniati**, EM Dadi Suyoko**, Zakindin Munasir**, Arwin AP Akib** \\ *Peserta Program Fellowship Divisi Alergi-Imunologi Departemen Ilmu Kesehatan Anak Fakultas \\ Kedokteran Universitas Indonesia \\ **Divisi Alergi-Imunologi Departemen Ilmu Kesehatan Anak Fakultas Kedokteran Universitas Indonesia
}

Latar belakang. Manifestasi klinis Lupus Eriternatosus Sistemik (LES) sangat bervariasi sehingga seringkali menyulitkan penegakan diagnosis. Skor aktivitas penyakit dan kerusakan organ belum diterapkan dalam pemantauan sehari-hari.

Tujuan. Mengetahui karakteristik pasien anak dengan LES yang berobat ke Departemen Ilmu Kesehatan Anak (IKA) RSCM.

Metode. Penelitian retrospektif deskriptif dengan data didapatkan dari rekam medik anak dengan LES periode 1 Januari 1995-31 Desember 2008.

Hasil. Dari 27 rekam medik yang memenuhi kriteria penelitian, tidak ada subjek berusia di bawah 5 tahun dan hampir seluruhnya perempuan. Manifestasi klinis terbanyak adalah ruam malar, artritis, artralgia, fotosensitivitas, dan demam. Kadar anti ds-DNA pada sebagian besar pasien menunjukkan peningkatan bermakna. Seluruh pasien mendapat kortikosteroid oral sebagai terapi inisial. Skor SLEDAI dan ACR Damage Index meningkat pada subjek dengan perjalanan penyakit yang progresif.

Kesimpulan. Karakteristik pasien LES pada penelitian ini sesuai denga kepustakaan. Pemantauan penyakit dengan skor bermanfaat dalam mencegah kerusakan organ. (Sari Pediatri 2009;11(2):108-12).

Kata kunci: lupus, ANA, komplemen, anti ds-DNA, nefritis, kortikosteroid, imunosupresan

upus Eritematosus Sistemik merupakan penyakit autoimun dengan pembentukan antibodi antinukleus (ANA), terutama terhadap double-stranded DNA (anti ds-

\footnotetext{
Alamat korespondensi

Dr. Zakiudin Munasir, Sp.A(K), Divisi Alergi Imunologi Departemen Ilmu Kesehatan Anak FKUI-RSCM, Jl. Salemba 6, Jakarta 10430. Telepon 021-3161144, Fax.: 021-3913982.
}

DNA).1 Pada LES terjadi proses inflamasi, vaskulitis, deposisi kompleks imun, serta vaskulopati yang luas, dengan manifestasi klinis yang bersifat episodik dan multisistem. ${ }^{1,2}$

Insidens LES pada anak sebesar 10-20 kasus/100.000 anak dan sangat jarang terjadi sebelum usia 5 tahun, sedangkan pada perempuan umumnya terjadi pada usia sesudah pubertas dan sebelum menopause. ${ }^{1-4}$ Perbandingan jumlah pasien perempuan dan lakilaki antara 5-10:1 tampaknya hormon estrogen yang 
berlebih dan aktivitas androgen yang inadekuat mengganggu respons imun. ${ }^{2}$ Penyakit LES lebih sering terjadi pada keluarga dengan riwayat LES atau penyakit autoimun lainnya.,6 Peran faktor genetik pada LES terletak pada gen dalam major histocompatibility complex, haplotipe yang rentan adalah DRB $1^{*} 08$ dan DRB1*03.1,7

Etiologi LES masih belum jelas, namun telah terbukti bahwa LES merupakan interaksi antara faktor genetik (disregulasi imun, hormon) dan lingkungan (sinar UVB, obat), yang berakibat pada terbentuk limfosit T dan B autoreaktif yang persisten. ${ }^{8}$ Diagnosis LES pada anak ditegakkan dengan terpenuhinya paling sedikit 4 dari 11 kriteria klasifikasi yang dibuat oleh American College of Rheumatology 1982, dengan sensitivitas $96 \%$ dan spesifisitas $100 \% .^{3}$ Demam intermiten atau menetap, lelah, berat badan turun, dan anoreksia merupakan gejala LES yang aktif. Kelainan dapat terjadi pada mukokutan (ruam malar, lesi diskoid, aloplesia, ulserasi mukosa mulut/ nasal), muskuloskeletal (artralgia, artritis), ginjal (hematuria, proteinuria, hipertensi), susunan saraf pusat/SSP (kejang, psikosis, halusinasi), jantung (perikarditis), pare (pleuritic), sindrom, antifosfolipid (tromboemboli), vaskulitis, mata (mata kering), dan gastrointestinal (mual, hepatitis). ${ }^{1,5}$

Gambaran laboratorium menunjukkan anemia (penyakit kronis atau hemolitik), limfopenia, dan trombositopenia; kombinasi purpura trombositopenia idiopatik dan anemia hemolitik akut (sindrom Evan's) sering terjadi. ${ }^{1,5}$ Urinalisis menunjukkan proteinuria, hematuria, dan silinder sel darah merah. ${ }^{1,8}$ Indikator inflamasi akut akan meningkat sesuai aktivitas penyakit sistemik. ${ }^{5}$ Terdapat pula antikoagulan lupus, antikardiolipin, dan antibodi antifosfolipid yang menyebabkan tromboemboli. ${ }^{1,9}$ Hampir seluruh pasien LES aktif menunjukkan ANA positif, namun hanya dengan ANA positif tanpa keterlibatan sistem organ dan pemeriksaan laboratorium, sulit untuk menegakkan diagnosis. ${ }^{1,10}$ Antibodi terhadap dsDNA merupakan kriteria patognomonik pada LES dan bila disertai penurunan kadar komplemen memiliki hubungan yang kuat dengan terjadinya nefritis lupus.,3,11

Obat anti inflamasi non-steroid dan anti malaria digunakan pada kasus yang tidak mengancam jiwa (artralgia, mialgia, dan sinovitis).,12 Glukokortikoid merupakan terapi utama. ${ }^{5}$ Prednison oral dosis rendah $(<0,5 \mathrm{mg} / \mathrm{kg} / \mathrm{hari})$ cukup untuk mengatasi demam, dermatitis, dan artritis, prednison oral dosis tinggi (1-2 $\mathrm{mg} / \mathrm{kg} /$ hari) untuk anemia hemolitik, gangguan SSP dan nefritis, sedangkan metilprednisolon intravena (30 mg/kg/hari, 1-3 hari) untuk mendapat efek yang cepat. Imunosupresan (azatioprin, siklofosfamid, metotreksat, siklosporin, mychophenolate mofetill $M M F)$ untuk mengontrol LES dan mencapai kualitas hidup yang lebih baik. ${ }^{1}$ Pasien LES memiliki risiko infeksi yang tinggi sehingga diperlukan tata laksana yang tepat serta pencegahan dengan vaksinasi. ${ }^{1,13}$ Tabir surya $(\mathrm{SPF}>15)$ berguna untuk mengurangi paparan sinar matahari. ${ }^{1}$

Pemantauan jangka panjang yang teratur terhadap aktivitas penyakit penting untuk mencegah timbulnya penyulit. Lupus Activity Index, SLE Disease Activity Index, Systemic Lupus Activity Measure, dan British Isles Lupus Assessment Group Activity Index merupakan skor untuk menilai aktivitas LES, sedangkan Systemic Lupus Intel-national Collaborating Clinics Damage Index untuk mengukur akumulasi kerusakan organ. ${ }^{1}$

\section{Metode}

Penelitian restrospektif deskriptif dilakukan di Departemen IKA RSCM periode 1 Januari 1995-31 Desember 2008. Data diperoleh dari rekam medis dengan kriteria inklusi, usia 0-18 tahun dan didiagnosis sebagai LES, sedangkan kasus yang tidak ada rekam medik tidak diikutsertakan dalam penelitian. Diagnosis dan definisi operasional untuk manifestasi klinis dan laboratorium berdasarkan kriteria ACR. Data diolah dengan menggunakan program SPSS versi 13.

\section{Hasil}

Selama 14 tahun terdaftar 60 pasien dengan diagnosis LES namun hanya 27 pasien yang memenuhi kriteria inklusi penelitian. Jumlah subjek perempuan dibandingkan laki-laki, 24:3 dan usia terbanyak antara 6-12 tahun (Gambar 1). Dua subjek perempuan memiliki ibu yang juga menderita LES.

\section{Manifestasi klinis dan laboratorium}

Ruam malar, artritis, artralgia, fotosensitivitas, dan demam merupakan manifestasi klinis terbanyak saat pasien pertama kah berobat ke RSCM (Gambar 2). 
Pemeriksaan darah tepi dan anti ds-DNA dilakukan pada seluruh subjek penelitian, pemeriksaan LED dan urinalisis pada 24 subjek, pemeriksaan ANA pada 19 pasien dan pemeriksaan kadar C3 dilakukan pada 25 pasien (Gambar 3).

\section{Tata laksana dan pemantauan}

Sebelas pasien mendapat prednison dan 16 pasien mendapat metilprednisolon sebagai terapi inisial. Dua subjek juga mendapat siklofosfamid (CPA) pulse saat

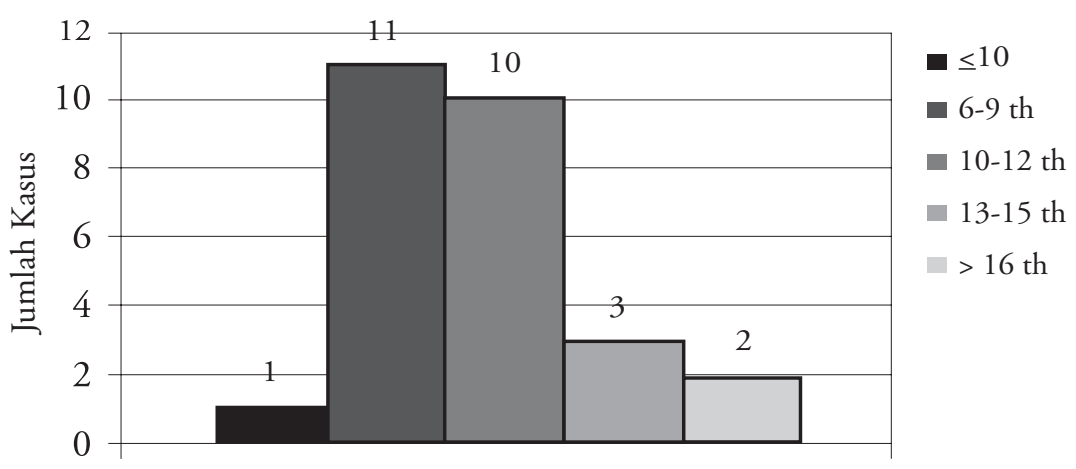

Gambar 1. Sebaran usia pasien LES anak di RSCM (1995-2008)

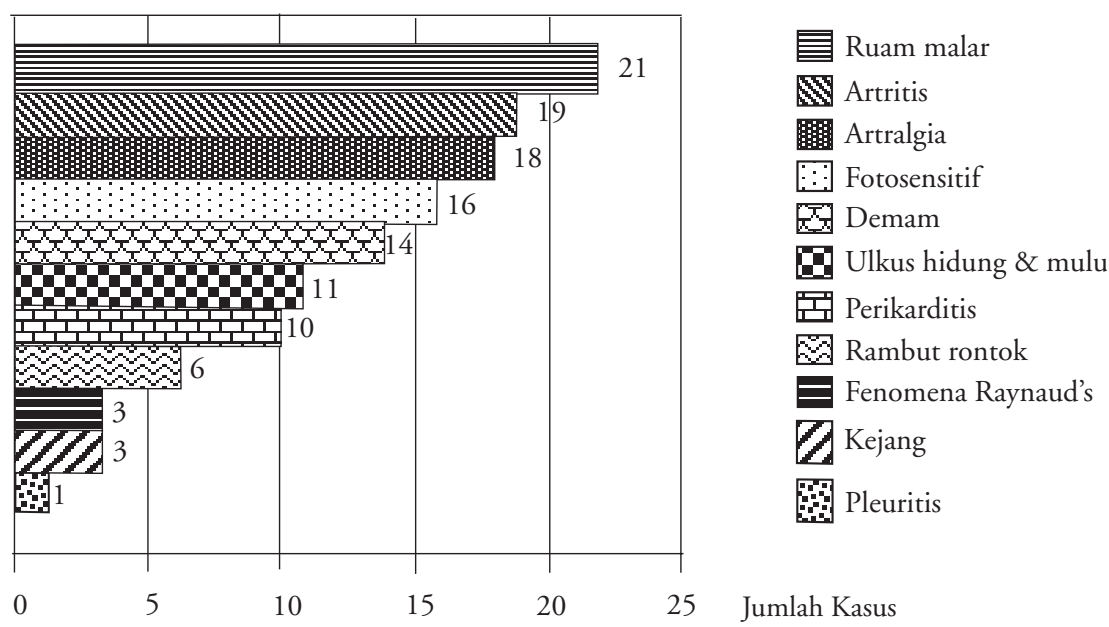

Gambar 2. Manifestasi klinis pasien LES anak di RSCM (1995-2008)

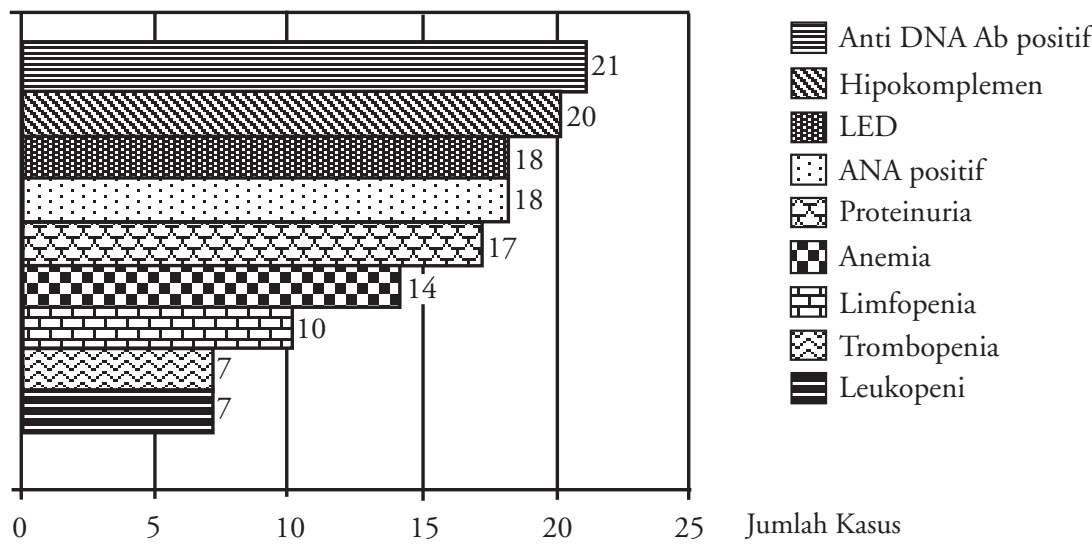

Gambar 3. Gambaran laboratorium pasien LES anak di RSCM (1995-2008) 
awal terapi dan 3 pasien mendapat CPA pulse dalam perjalanan terapi. Satu pasien mendapat mycho plenolate mofetil (MMF) karena menolak CPA pulse dan satu pasien mendapat MMF karena tidak menunjukkan respons yang baik dengan kortikosteroid oral dan CPA pulse. Pada akhir pengamatan/akhir kunjungan terdapat peningkatan skor SLEDAI dan skor ACR Damage Index pada 4 pasien, 3 di antaranya meninggal dunia, sedangkan 1 hilang dari pengamatan.

\section{Diskusi}

Hampir seluruh subjek berjenis kelamin perempuan, sesuai dengan kepustakaan yang menyatakan bahwa LES terutama terjadi pada perempuan. ${ }^{2}$ Saat timbul gejala pertama sebagian besar subjek berusia 6-12 tahun dan tidak ada yang berusia di bawah 5 tahun. ${ }^{3,4}$ Jumlah pasien usia 13-18 tahun yang lebih sedikit dibandingkan usia 6-12 tahun kemungkinan disebabkan anak lebih dari 12 tahun tidak lagi berobat ke dokter anak. lbu dari 2 pasien juga menderita LES, bahwa pasien LES cenderung memiliki anggota keluarga yang juga menderita LES. ${ }^{5}$

Demam sebagai gejala awal dialami oleh 24 pasien namun saat berobat hanya terdapat pada 14 pasien, hal ini kemungkinan karena gejala awal LES yang tidak khas sehingga pasien telah mendapat terapi simtomatik. Artralgia terdapat pada 19 pasien, merupakan salah satu manifestasi klinis utama pada $90 \%$ pasien LES. Empat dari 22 pasien dengan ruam malar memiliki anti ds-DNA yang negatif, sebaliknya 5 pasien yang tidak menunjukkan roam malar memiliki anti ds-DNA yang positif, ruam malar sangat mencurigakan LES namun tidak patognomonik. Fotosensitivitas pada 18 pasien, bahwa sinar matahari dapat mencetuskan timbulnya ruam malar pada $30 \%$ pasien. ${ }^{5}$ Delapan dari 11 pasien dengan ulserasi mukosa mulut menunjukkan anti ds-DNA positif, lesi mukosa mulut menyokong diagnosis LES. ${ }^{1,3}$

Efusi perikard dan perikarditis terdapat pada 9 pasien dan hanya 2 pasien disertai kardiomiopati hipertrofi, perikarditis pada LES jarang menyebabkan tamponade atau kardiomegali. ${ }^{1,5}$ Pleuritik dan efusi pleura adalah gejala yang dialami oleh $60 \%$ pasien LES dengan gejala respiratori, ${ }^{1,5}$ pada penelitian kami pleuritik hanya terdapat pada 4 pasien, kemungkinan karena foto toraks tidak dilakukan pada seluruh pasien. Tiga pasien menderita kejang pada awal penyakit dan
4 pasien lain kejang di akhir pengamatan, kejang dapat merupakan gejala awal. ${ }^{1}$ Urinalisis pada 24 pasien menunjukkan proteinuria ringan pada 9 pasien dan proteinuria bermakna pada 10 pasien, proteinuria merupakan manifestasi klinis tersering dari nefritis lupus. ${ }^{12}$ Fenomena Raynaud's terdapat pada 2 pasien dengan keluhan telapak kaki terasa tebal, timbul ulkus dan krusta kehitaman pada telapak kaki, vaskulitis pada LES mengenai pembuluh darah kecil, arteriol, dan venula. ${ }^{1}$

Sembilan dari 14 pasien menderita anemia menunjukkan kadar hemoglobin di atas $7 \mathrm{~g} / \mathrm{dL}$, anemia pada LES umumnya ringan. ${ }^{1,5}$ Pemeriksaan LED pada 24 pasien menunjukkan peningkatan LED pada 18 pasien, indikator inflamasi akut akan meningkat sesuai dengan aktivitas penyakit sistemik. ${ }^{1}$ Pemeriksaan ANA pada 19 pasien menunjukkan hasil yang positif pada 18 pasien, 3 di antaranya dengan gejala roam malar, demam dan artralgia ringan dan tidak disertai peningkatan anti ds-DNA maupun penurunan kadar C3. Meskipun ANA terdapat pada hampir seluruh pasien LES aktif, namun diagnosis LES sulit ditegakkan hanya dengan ANA positif tanpa keterlibatan system organ atau pemeriksaan laboratorium yang karakteristik. ${ }^{1,8,10}$ Empat dari 5 pasien dengan anti ds-DNA negatif menunjukkan perjalanan penyakit yang tidak progresif, anti ds-DNA merupakan pemeriksaan yang karakteristik untuk LES.1,8 Dari 20 pasien dengan kadar C3 yang rendah didapatkan proteinuria pada 17 pasien, kadar komplemen merupakan pemeriksaan penunjang terpenting pada LES yang disertai gangguan ginjal.

Glukokortikoid merupakan terapi farmakologi utama pada LES. ${ }^{14}$ Pada penelitian kami seluruh pasien mendapat GK oral sebagai terapi inisial. Siklofosfamide digunakan pada LES dengan manifestasi klinis berat, ${ }^{7}$ pasien mendapat tambahan CPA dengan indikasi nefritis lupus dan 1 pasien dengan vaskulitis lugs. Disimpulkan hampir seluruh pasien adalah perempuan dan tidak ada yang berusia kurang dari 5 tahun. Manifestasi klinis terbanyak adalah ruam malar, artralgia, fotosensitivitas, demam, ulserasi mukosa mulut, dan rambut rontok. Anti ds-DNA yang positif terdapat pada sebagian besar pasien. Seluruh pasien menerima glukokortikoid oral sebagai terapi inisial. Penggunaan skor untuk memantau aktivitas penyakit dan kerusakan organ bermanfaat untuk meminimalkan morbiditas dan mortalitas akibat LES. 


\section{Daftar Pustaka}

1. Petty RE, Laxer RM. Systemic Lupus Erythematosus. Dalam : Cassidy JT, Petty RE, penyunting. Textbook of pediatric rheumatology. Edisi ke-5. Philadelphia: Elsevier Saunders; 2005.h.342-91.

2. Mok CC, Lau CS. Pathogenesis of systemic lupus erythematosus. Diunduh dari http://w-v,vw.iclip,patl-t. coin. Diakses tanggal 24 Februari 2009.

3. Tucker LB. Making the diagnosis of systemic erythematosus in children and adolescent. Lupus 2007,16:546-9.

4. Font J, Cervera R, Espinosa G. Systemic lupus erythematosus (SLE) in childhood: analysis of clinical and immunological findings in 34 patients and comparison with SLE characteristics in adults. Ann Rheum Dis 1998;57:456-9.

5. Schriber L, Neill SO. Systemic lupus erythematosus : an overview for GPs. Medical Progress 2005, 557-62.

6. Sestak AL, O'Neil KM. Familial lupus and antiphospholipid syndrome. Lupus 2007:16;556-63.

7. Ramoya AS, Finholt C, Lilleby V. Systemic lupus erythematosus and the extended major histocompatibility complex-evidence for several predisposing loci. Rheumatology 2005:44;1368-73.

8. Akib AAP, Soepriadi M, Setiabudiawan B. Lupus eritematosus sistemik. Dalam: Arwin AAP, Munasir Z,
Kurniati N, penyunting. Buku ajar alergi - imunologi anak. Edisi ke-2. Jakarta: Ikatan Dokter Anak Indonesia; 2007.h.346-73.

9. Male C, Foulon D, Hoogendoom H. Predictive value of persistent versus transient antiphospholipid antibody subtypes for the risk of thrombotic events in pediatric patients with systemic lupus erythematosus. Blood 2005;106:4152-8.

10. Guidelines for referral and management of systemic lupus erythematosus in adults. Arthritis and rheumatism 1999; 42:1785-95.

11. Hernandez JC, Ros JO, Labrador M. Predictors of poor renal outcome in patients with lupus nephritis treated with combined pulses of cyclophosphamide and methylprednisolone. Lupus 2003;12:287-96.

12. Walker SE. The importance of sex hormones in systemic lupus erythematosus. Dalam: Wallace DJ, Hahn BH, penyunting. Dubois' lupus erythematosus. Edisi ke7. Philadelphia: Lippincott Williams \& Wilkins; 2007. h. 273-85.

13. Heyneman CA. Systemic lupus erythematosus: a therapeutic update. Journal of Pharmacy Practice 2009; 22:29-52.

14. Mitsikostas DD, Sfikafis PP, Goadsby PJ. A meta-analysis for headache in systemic lupus erythematosus: the evidence and the myth. Brain 2004;127:1200-9. 